\title{
THE GENUS ECCLISOPTERYX (INSECTA: TRICHOPTERA: LIMNEPHILIDAE) IN CROATIA: DISTRIBUTION AND CONSERVATION ASPECTS
}

\author{
Ivan VučKović ${ }^{1}$, Renata ĆuK ${ }^{2}$, Darko Cerjanec ${ }^{3}$, Iva Vidaković ${ }^{\text {, }}$ \\ Mladen Plantak ${ }^{1}$, Marta Srebočan ${ }^{1}$ \& Mladen KuČinić ${ }^{4}$
}

${ }^{1}$ Elektroprojekt d.d., Civil and Architectural Engineering Department, Water Resources, Nature and Environmental protection, Alexandera von Humboldta 4, 10000 Zagreb, Croatia (e-mail: ivan.vuckovic@elektroprojekt.hr)

${ }^{2}$ Hrvatske vode, Central Water Management Laboratory, Ulica grada Vukovara 220, 10000 Zagreb, Croatia

${ }^{3}$ Primary School Barilović, 47252 Barilović 96

${ }^{4}$ Department of Biology, (Laboratory for Entomology), Faculty of Science, University of Zagreb, Rooseveltov trg 5, 10000 Zagreb, Croatia

Vučković, I., Ćuk, R., Cerjanec, D., Vidaković, I., Plantak, M., Srebočan, M. \& Kučinić, M.: The genus Ecclisopteryx (Insecta: Trichoptera: Limnephilidae) in Croatia: Distribution and conservation aspects. Nat. Croat., Vol. 25, No. 2., 267-278, 2016, Zagreb.

This paper presents the distribution of two species of the genus Ecclisopteryx in Croatia based on literature data and the new records: E. keroveci and E. ivkae. The species E. ivkae was recorded at eight sites in the catchment area of the Cetina River, while E. keroveci occurs within the catchment area of the Kupa River and along the Veličanka River. Due to the restricted distribution, we proposed conservation and protection measures for both species.

Key words: Ecclisopteryx keroveci, Ecclisopteryx ivkae, new records

Vučković, I., Ćuk, R., Cerjanec, D., Vidaković, I., Plantak, M., Srebočan, M. \& Kučinić, M.: Rod Ecclisopteryx (Insecta: Trichoptera: Limnephilidae) u Hrvatskoj: rasprostranjenost $\mathrm{i}$ aspekti zaštite. Nat. Croat., Vol. 25, No. 2., 267-278, 2016, Zagreb.

U ovom radu je prikazana rasprostranjenost dviju vrsta roda Ecclisopteryx u Hrvatskoj: E. keroveci i E. ivkae, na osnovu literaturnih podataka i novih nalaza. Vrsta E. ivkae zabilježena je na slivnom području rijeke Cetine, a vrsta E.keroveci na slivnom području Kupe i rijeci Veličanki. U radu su predložene i mjere zaštite za obje vrste, a odnose se na zaštitu kako samih vrsta tako i staništa na kojem obitavaju.

Ključne riječi: Ecclisopteryx keroveci, Ecclisopteryx ivkae, novi nalazi

\section{INTRODUCTION}

The genus Ecclisopteryx Kolenati, 1848 (subfamily Drusinae; family Limnephilidae) is currently represented by seven species in Europe and two species in the Asian part of Turkey (Malicky, 2004; Previšić et al., 2014; SipAhiler, 2015). In Europe E. dalecarlica Kolenati, 1848, E. madida (McLachlan, 1867) and E. guttulata (Pictet, 1834) are relatively widely distributed species occurring in several ecoregions according to ILLIES, 1978 with partially overlapping ranges (Graf et al., 2008; Graf \& Schmidt-KLOIBER, 2011). The following two species are endemic with a limited distribution in the Alps: E. asterix, Ma- 

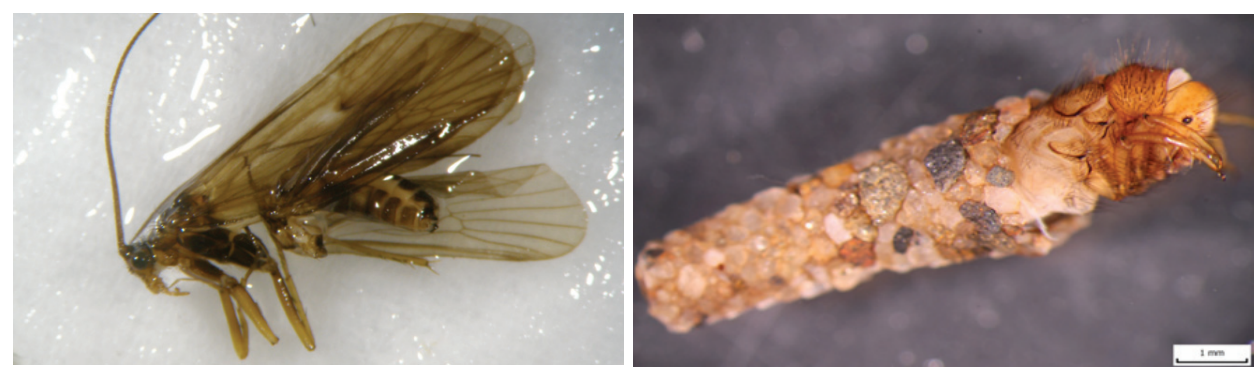

Fig. 1. E. keroveci, a) adult; b) larva
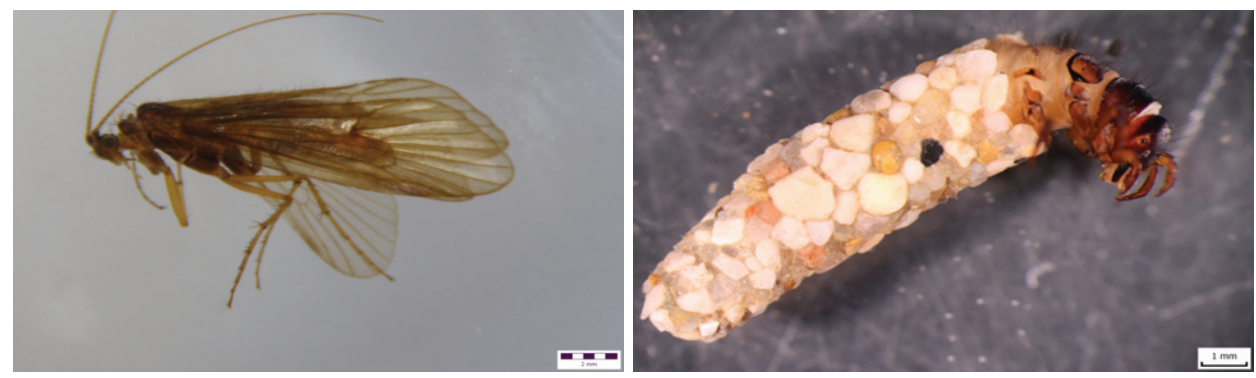

Fig. 2. E. ivkae, a) adult; b) larva

licky, 1979 occurs in the Karawanken and Julian Alps while the species E. malickyi Moretti, 1991 inhabits the Lessinian Alps (Graf et al., 2008, 2011; Graf \& Schmidt -Kloiber, 2011). The adults of five European species E. madida, E. asterix, E. malicky, E. dalecarlica and E. guttulata are morphologically well separated as larva and adults (MALICKY, 2004; WARINGER \& Graf, 2011; Previšić et al., 2014). Recently, two new species from the Western Balkans have been described, based on the results of DNA sequence analysis and morphological features: E. keroveci Previšić, Graf \& Vitecek, 2014 from the type locality at the mouth of the Jabučica River in Sutjeska National park (Bosnia and Herzegovina) (Fig. $1 \mathrm{a}$ and $1 \mathrm{~b}$ ) and E. ivkae Previšić, Graf \& Vitecek, 2014 from the type locality at the Glavaš spring of the Cetina River (Croatia) (Fig. 2a and 2b) (Previšić et al., 2014). Both of these species are closely related to E. dalecarlica and can be readily identified in both adult and larval stages (Previšić et al., 2014). Due to these new descriptions, it is now recognized that E. keroveci from Western Balkans was formerly misidentified as E. dalecarlica in Croatia (Previšić \& Popijač, 2010, VučKović, 2011, VučKović et al., 2011), Bosnia and Herzegovina (Stanić-Koštroman et al., 2015) and Montenegro (Oláh \& Kovács, 2014). One faunustic data of E. keroveci from Kosovo (IвRAHImi, 2104) was corrected and supplemented with new finding of this species in paper Iвrahim et al. (2015). OláH \& Kovacs (2014) found E. keroveci in Republic of Macedonia for the first time at two localities, Šarmountain and Vevčani spring (Kučınić et al., 2016). The literature data of Radovanović (1935) and Marinković-Gospodnetić (1970) for the species E. guttulata in Bosnia and Herzegovina was probably falsely determined.

The latest study by SiPAHILER, 2015 reports two new Ecclisopteryx species from Turkey: E. oylat from Bursa Province in the Marmara Region and E. aksu from Isparta Province in southern Turkey. Both new species are morphologically most similar and potentially 
Tab. 1. Localities of Ecclisopteryx in Croatia with short-codes, stage, ecoregion and date of the record (*literature data). The short-codes correspond to those in Figs 4 and 5; Lv. - Larva, Ad. - Adult

\begin{tabular}{|c|c|c|c|c|}
\hline $\begin{array}{l}\text { short- } \\
\text { code }\end{array}$ & Locality & Stage & Ecoregion & Date \\
\hline \multicolumn{5}{|c|}{ Ecclisopteryx keroveci } \\
\hline 1. & The Čabranka River - spring* & Ad. & ER 5 & May 2013 \\
\hline 2. & The Čabranka River -mouth & Lv., Ad. & ER 5 & $\begin{array}{l}\text { Stage Lv., May 2013, } \\
\text { Stage Ad., May } 2015\end{array}$ \\
\hline 3. & The Kupa River - Brod na Kupi & Ad. & ER 5 & May 2015 \\
\hline 4. & $\begin{array}{l}\text { The Kupa River - after the confluence with } \\
\text { the Čedanj River }\end{array}$ & Lv. & ER 5 & October 2013 \\
\hline 5. & $\begin{array}{l}\text { The Kupa River - before the confluence with } \\
\text { the Čabranka River* }\end{array}$ & Lv. & ER 5 & May 2013 \\
\hline 6. & The Kupica River - mouth & Lv. & ER 5 & October 2013 \\
\hline 7. & The Belica River - bridge at Kuželj* $^{*}$ & Ad. & ER 5 & July 2012 \\
\hline 8. & The Dretulja River - Plaški, upper reach & Ad. & ER 5 & May 2015 \\
\hline 9. & The Curak stream - mouth & Lv. & ER 5 & May 2013 \\
\hline 10. & The Veličanka River - upper reach & Ad. & ER 11 & May 2015 \\
\hline \multicolumn{5}{|c|}{ Ecclisopteryx ivkae } \\
\hline 11. & The Cetina River - Glavaš spring* & Lv. & ER 5 & $\begin{array}{l}\text { Stage Lv., November } 2014 \\
\text { Stage Ad., May, July 2005, } \\
\text { 2007, } 2012\end{array}$ \\
\hline 12. & The Cetina River - Vukovića spring & Lv. & ER 5 & February 2015 \\
\hline 13. & The Nele spring & Lv. & ER 5 & February 2015 \\
\hline 14. & The Batice spring & Lv. & ER 5 & February 2015 \\
\hline 15. & The Cetina River - Red bridge* & Lv. & ER 5 & February 2015 \\
\hline 16. & The Cetina River -Vinalić* & Lv. & ER 5 & February 2015 \\
\hline 17. & The Rumin River - Rumin Veliki spring & Lv. & ER 5 & February 2015 \\
\hline 18. & The Rumin River - Rumin Mali spring & Lv. & ER 5 & February 2015 \\
\hline
\end{tabular}

closely related to E. dalecarlica (SipAhiler, 2015). The larvae of species E. oylat and E. aksu have not been described.

This paper presents detailed distribution data on the genus Ecclisopteryx in Croatia and new observations on the ecology of both species E. keroveci and E. ivkae. Additionally, some conservation aspects for these species and their features habitats are discused.

\section{MATERIAL \& METHODS}

\section{Research area}

Adults and larvae of the genus Ecclisopteryx, were collected by several rivers in Croatia. Most of the records originate from the Kupa and Cetina catchment area (Ecoregion 


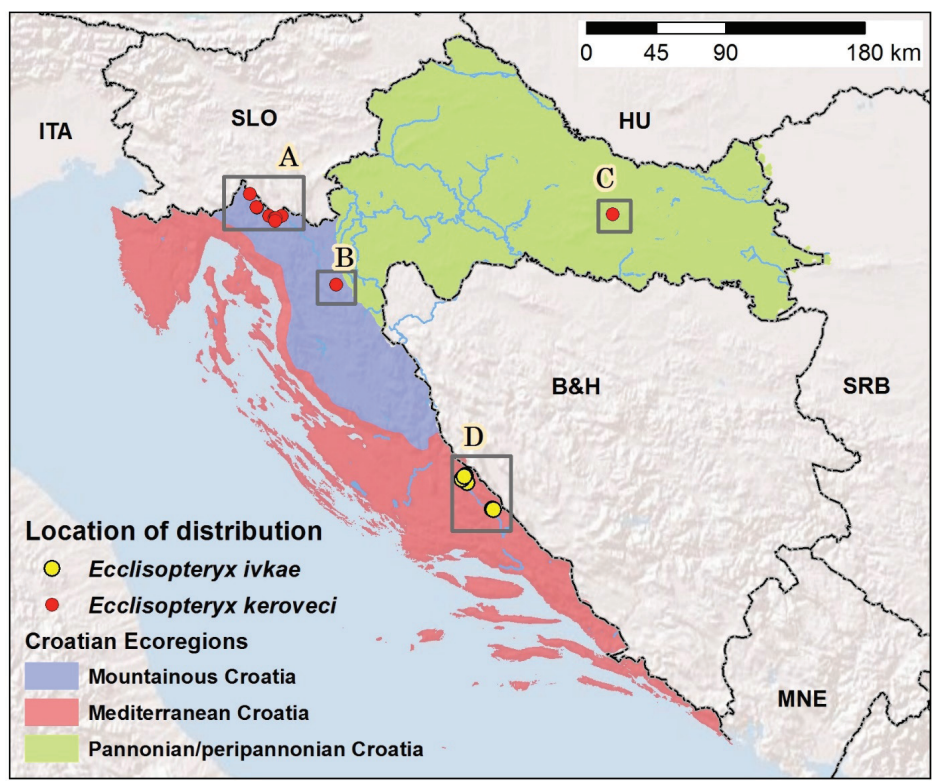

Fig. 3. Distribution of Ecclisopteryx species in Croatia

5 (ER 5) - Dinaric Western Balkan), while one record originates from the Veličanka River at Mt. Papuk (Ecoregion 11 (ER 11) - Hungarian lowlands) (ILLIEs, 1978) (Fig. 3, Tab. 1). Records in the Kupa catchment area include the upper course of the Kupa River as well as its tributaries, the Kupica, the Čabranka, the Belica and the Curak rivers. The Kupa catchment area covers $10,236 \mathrm{~km}^{2}, 8,412 \mathrm{~km}^{2}$ of which is in Croatia (NARodne Novine, 2008). The length of the Kupa River is 294 km; its spring is located in Kupari village while the mouth into the Sava River is at Sisak. The upper course of the Kupa River, the Čabranka, the Kupica and the Dretulja rivers are classified as „Medium and large montane and upland rivers" (HR-R_7), while the Belica and the Curak rivers are classified as "Small mountainous and upland streams" (HR-R_6) (NAROdNE Novine, 2013, 2014). The Dretulja River is a tributary of the Mrežnica River and is classified as "Medium and large mountainous and upland river" (HR-R_7) while the Veličanka River belongs to the "small lowland rivers with gravel and pebble substrate" (HR-R_2B) river type (NAROdNE NOvine, 2013, 2014).

The Cetina River catchment covers $4,145 \mathrm{~km}^{2}, 1,531 \mathrm{~km}^{2}$ of which is in Croatia (NARodne nOvine, 2008). The length of the Cetina River is $104 \mathrm{~km}$, with the main spring situated at Glavaš while the mouth into Adriatic Sea is at Omiš. The upper course of the Cetina River is classified as a "Medium and large upland rivers" (HR-R_12) (NARodNE NOvine, 2013, 2014). The Rumin is a small left tributary of the Cetina River; its total length is $1,4 \mathrm{~km}$.

\section{Sampling and laboratory work}

The data in this study originate from to the following sources: 1) the EU Natura 2000 Integration Project (NIP) project in which adult caddisflies were sampled at 105 localities all over Croatia in the period from 2014 to 2015; 2) individual research; 3) the regular 
monitoring of surface water quality in which caddisfly larvae are sampled as part of benthic macroinvertebrates (unpublished data of Hrvatske vode); 4) literature data (Previšić et al., 2014; OláH \& Kovács, 2014 Stanić-Koštroman et al., 2015; Ibrahimi et al., 2014, 2015; Kučınıć et al., 2016).

Most of the adult caddisfly specimens were collected during 2014 and 2015 by light trapping, using $6 \mathrm{~W}$ or $8 \mathrm{~W}$ ultraviolet (UV) fluorescent tubes powered by a $12 \mathrm{~V}$ battery. Larvae were collected by hand-net with a mesh size of $500 \mu \mathrm{m}$ and by handpicking.

The collected material was preserved and stored in 96\% ethanol. Adult specimens are deposited in the Croatian Natural History Museum in Zagreb in the collection NIP Trichoptera while larvae are deposited in the Central Water Management Laboratory of Hrvatske vode. Macrophotographing of larvae and adults was done at the Faculty of Forestry, University of Zagreb (using a Leica Wild MZ8 stereomicroscope and Olympus SP-500 UZ digital camera) and Central Water Management Laboratory of Hrvatske vode (using stereomicroscope SZX10 and Canon EOS 1100D STL digital camera) processed with the computer program Olympus Quick Photo Camera.

The physico-chemical parameters of water from most sampling stations (for the year of 2013) were provided by Hrvatske vode and include water temperature $\left({ }^{\circ} \mathrm{C}\right)$, dissolved oxygen $\left(\mathrm{mg} \mathrm{O}_{2} / 1\right)$, oxygen saturation $(\%)$, conductivity $(\mu \mathrm{S} / \mathrm{cm}), \mathrm{pH}$, alcalinity $(\mathrm{mg}$ $\left.\mathrm{CaCO}_{3} / \mathrm{l}\right), \mathrm{COD}\left(\mathrm{mg} \mathrm{O}_{2} / \mathrm{l}\right), \mathrm{BOD}_{5}\left(\mathrm{mg} \mathrm{O}_{2} / \mathrm{l}\right)$, ammonia $(\mathrm{mg} \mathrm{N} / \mathrm{l})$, nitrites $(\mathrm{mg} \mathrm{N} / \mathrm{l})$, total nitrogen (mg N/l), orthophosphates (mg P/l) and total phosphorus (mg P/l). Two sampling stations (Nele Spring, Rumin - Veliki Rumin Spring) are not covered by national water quality monitoring and therefore the physico-chemical parameters were taken from a previous study by VučKović, 2011.

\section{RESULTS \& DISCUSSION}

\section{Distribution}

All hitherto known records of E. keroveci and E. ivkae from Croatia are presented in Tab. 1 and (Fig. 3).

E. keroveci has a disjunct distribution from the Slovenian-Croatian border, through Bosnia and Herzegovina, Montenegro and Kosovo to Macedonia (Previšić et al., 2009; Previšić \& Popijač, 2010, VučKović, 2011, Vuč́ović et al., 2011; OláH \& Kovács, 2014, Ibrahimi, 2014, Ibrahimi, 2015; Stanić-Koštroman et al., 2015) (Fig. 6) and is considered endemic for the ER 5 (Previšić et al., 2014).

In Croatia, former studies recorded the species in a small area in Gorski kotar at three localities in ER5 (according to IlLIES, 1978), or in Central-mountain area (BERTIć et al., 2001) (Fig. 3). Our research increased the records of five new localities in the Centralmountain area (The Čabranka River - mouth, The Kupa River - Brod na Kupi, The Kupa River - after the confluence with the Čedanj River, The Kupica River - mouth The Curak stream - mouth), one records in Ogulin-Plaški submountain valley (The Dretulja River - Plaški, upper reach) which are situated in ER5. The locality at the Veličanka River - upper reach is in ER11 (according to IlLIES, 1978) and in the Pannonian-Peripannonian region (BERTić et al., 2001) (Fig. 3, 4), which represents the first finding of this species outside the ER5. Such a pattern of disjunctive distribution is not unusual within the subfamily Drusinae and is a consequence of the ecological demands of these species as well as geological and hydrological processes in the past (Previšić et al., 2014.) A similar distribution is found in case of e.g., Drusus schmidi (Previšić et al., 2013; Kučınić et al., 2014). 


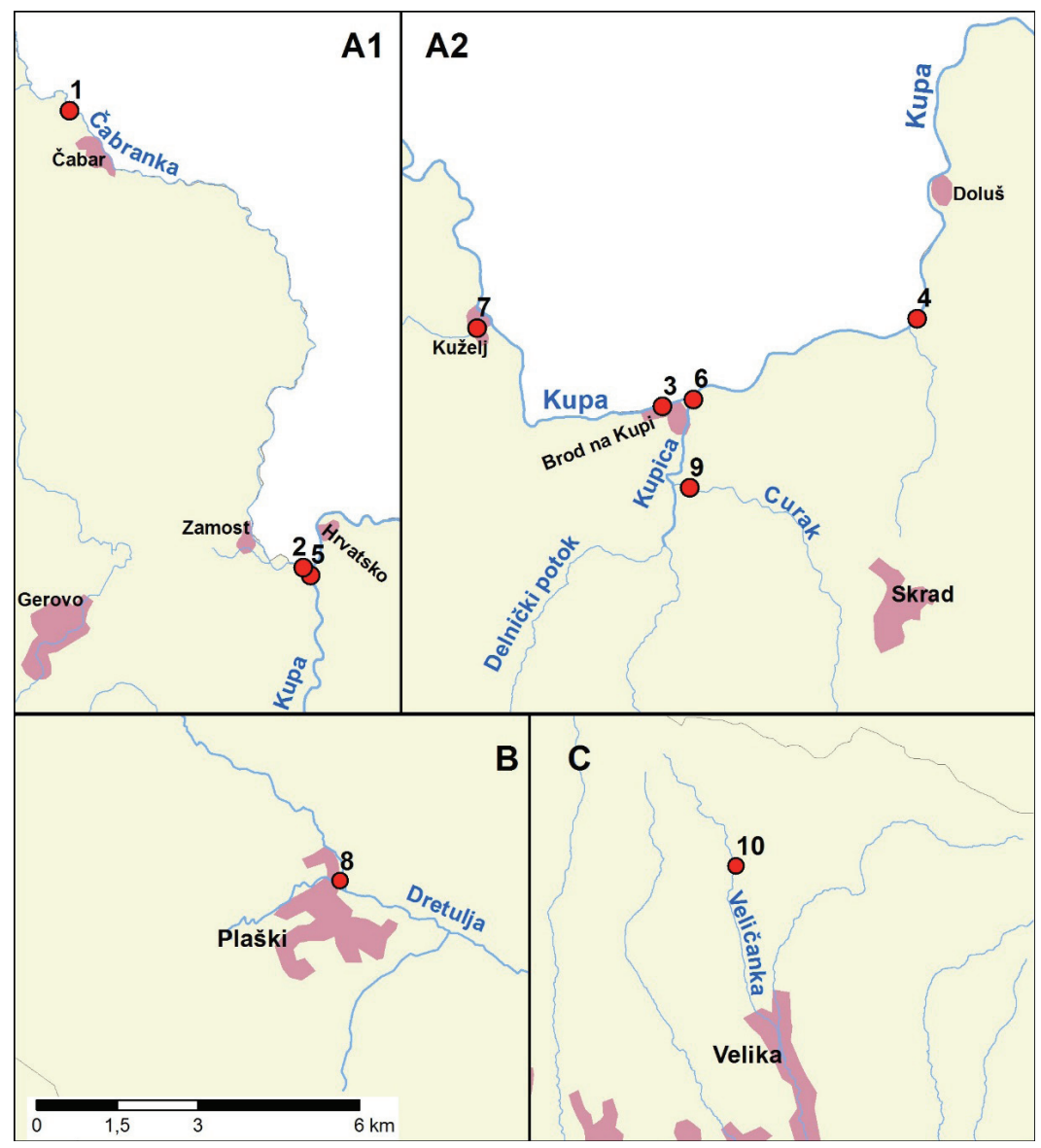

Fig. 4. Distribution of E. keroveci in the Kupa, the Čabranka, the Curak and the Kupica rivers (detail A of the Fig. 4) in the Dretulja (detail B of the Fig. 4) and the Veličaka River (detail C of the Fig. 4)

On the other hand E. ivkae is a microendemic species restricted to a few springs and spring areas in the catchment area of the Cetina River (Fig. 3, 5). This study presents new records from springs of the Cetina River but also from its tributary, the Rumin River. With the new findings areal for E. ivkae was extended about $20 \mathrm{~km}$ to the south. Such a localized distribution is confirmed by several recent faunistic studies that did not recover the species in any other part of the country. The detailed studies of Marinković-Gospodnetić $(1978,1979)$ and Stanić-Koštroman et al., 2012 do not list any species from the genus Ecclisopteryx in the western parts of Bosnia and Herzegovina, indicating that the species does not occur on the eastern sides of Mt. Dinara and Mt. Kamešnica which form the natural border between Croatia and Bosnia and Herzegovina. A similar distribution observed in Drusus croaticus (Insecta, Trichoptera), which is recorded only on the western slopes of Mt. Lička Plješivica (Croatia) but not on the eastern slopes of the same mountain (Kučinić et al., 2014). In contrast eight endemic species of the Drusus bosnicus Group are distributed in Bosnia and Herze- 


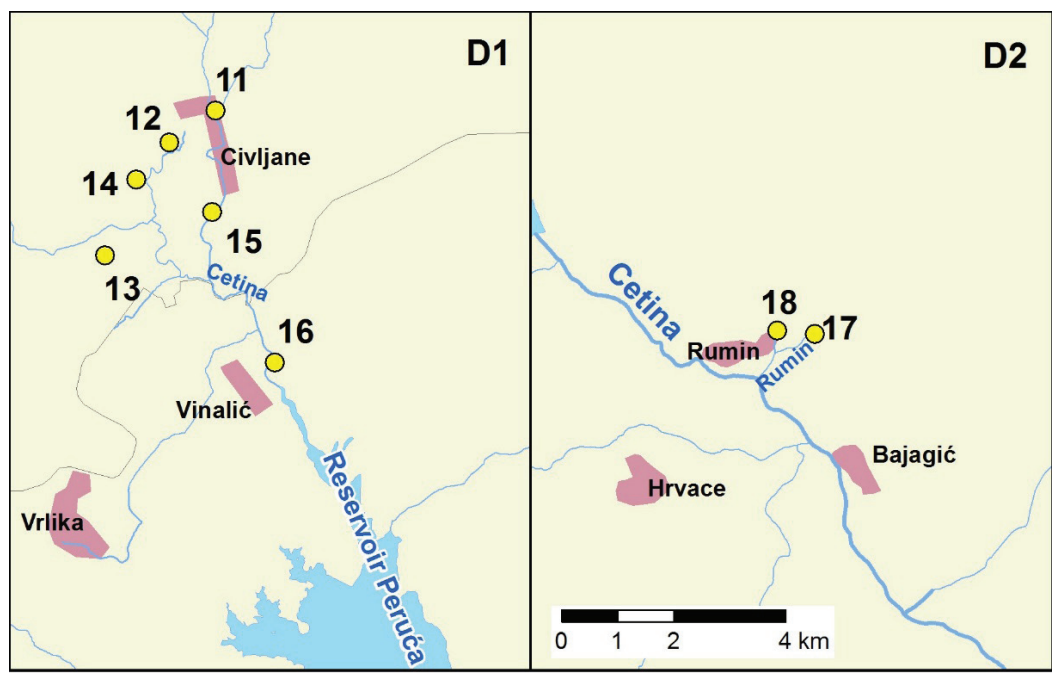

Fig. 5. Distribution of E. ivkae in the Cetina River and the Rumin River (details D of the Fig. 6)

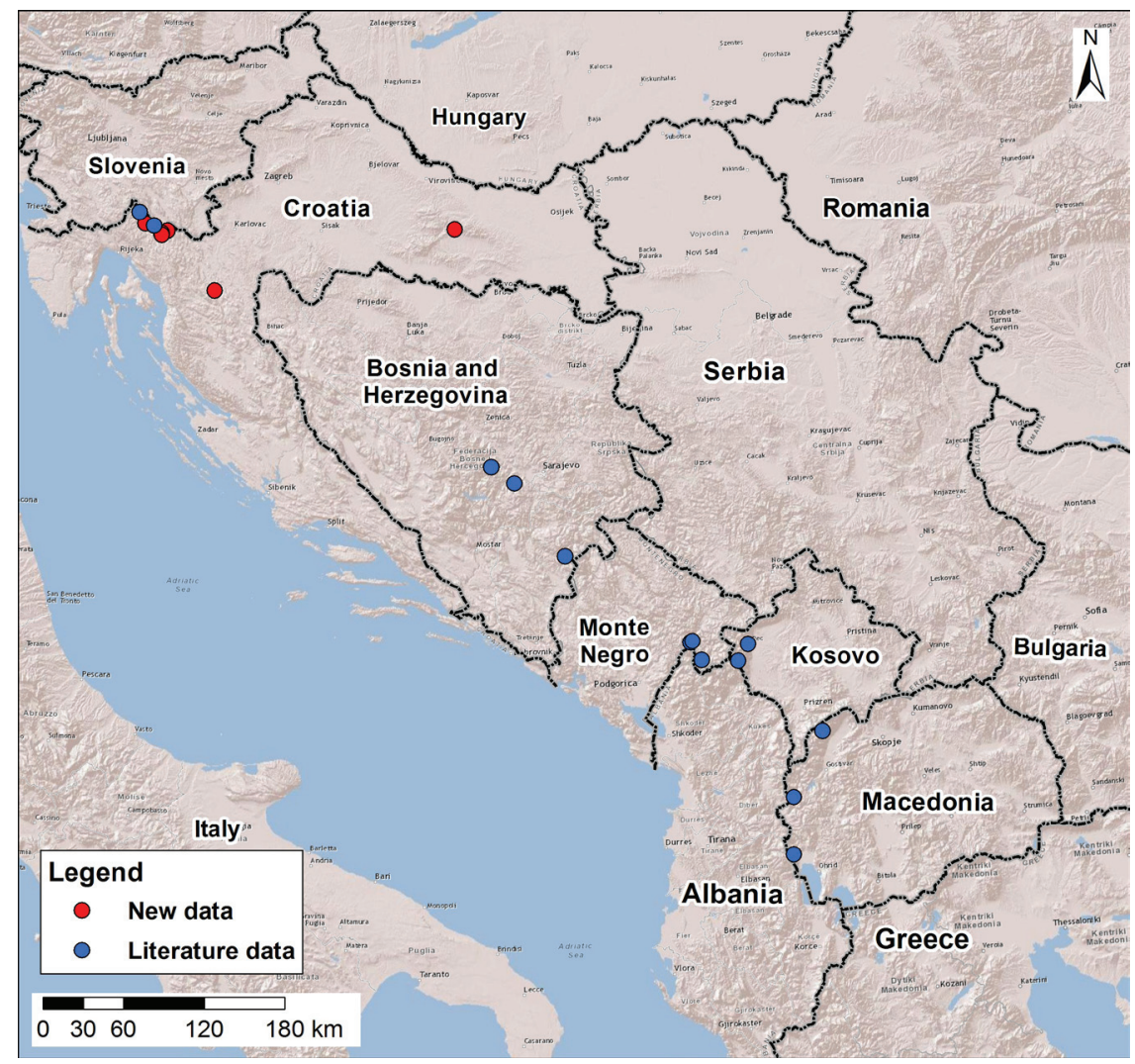

Fig. 6. Distribution of E. keroveci in the Western Balkan (according to literature data and new records). 


\begin{tabular}{|c|c|c|c|c|c|c|c|c|c|c|c|c|c|c|c|}
\hline 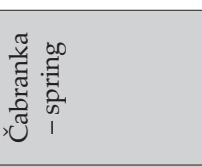 & 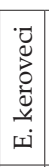 & 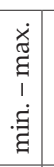 & $\begin{array}{l}2 \\
0 \\
1 \\
1 \\
\stackrel{1}{n}\end{array}$ & $\begin{array}{l}8 \\
8 \\
1 \\
1 \\
1 \\
0 \\
0 \\
0 \\
0\end{array}$ & 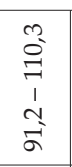 & ' & $\left|\begin{array}{c}1 \\
\infty \\
1 \\
8 \\
8 \\
\infty\end{array}\right|$ & $\begin{array}{l}80 \\
80 \\
1 \\
\text { 今े } \\
\text { ल }\end{array}$ & $\begin{array}{c}12 \\
\rightarrow \\
1 \\
0 \\
0\end{array}$ & $\mid \begin{array}{c}10 \\
\stackrel{7}{1} \\
+ \\
0 \\
0\end{array}$ & $\begin{array}{l}12 \\
0 \\
0 \\
1 \\
1 \\
0 \\
0 \\
0 \\
0\end{array}$ & $\begin{array}{l}0 \\
0 \\
0 \\
1 \\
1 \\
12 \\
0 \\
0\end{array}$ & 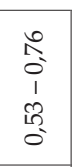 & $\begin{array}{l}\vec{z} \\
0 \\
0 \\
1 \\
1 \\
0 \\
0 \\
0\end{array}$ & $\begin{array}{l}2 \\
0 \\
0 \\
1 \\
0 \\
0 \\
0\end{array}$ \\
\hline 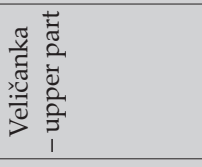 & 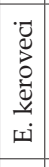 & 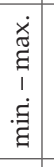 & $\begin{array}{l}0 \\
8 \\
\text { N } \\
1 \\
0 \\
0 \\
0\end{array}$ & $\begin{array}{l}\text { त् } \\
= \\
1 \\
1 \\
\infty \\
\infty \\
\infty\end{array}$ & $\begin{array}{l}5 \\
5 \\
0 \\
1 \\
2 \\
2 \\
2\end{array}$ & 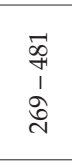 & $\mid \begin{array}{c}0 \\
9 \\
\infty \\
1 \\
8 \\
8 \\
\infty \\
\infty\end{array}$ & 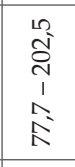 & 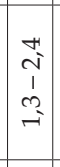 & $\mid \begin{array}{l}0 \\
\stackrel{2}{7} \\
1 \\
6 \\
0\end{array}$ & $\begin{array}{l}2 \\
0 \\
0 \\
1 \\
0 \\
0 \\
0\end{array}$ & $\mid \begin{array}{l}10 \\
-1 \\
1 \\
0 \\
0 \\
0 \\
0\end{array}$ & $\begin{array}{l}\stackrel{a}{\rightarrow} \\
1 \\
\stackrel{-}{\Rightarrow}\end{array}$ & $\begin{array}{l}5 \\
0 \\
0 \\
1 \\
1 \\
0 \\
0 \\
0\end{array}$ & $\begin{array}{l}8 \\
0 \\
0 \\
1 \\
0 \\
0 \\
0\end{array}$ \\
\hline 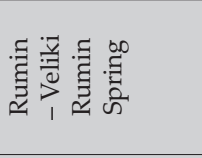 & 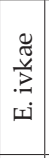 & 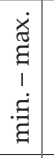 & $\begin{array}{l}\stackrel{+}{2} \\
\stackrel{2}{2} \\
1 \\
\text { L } \\
\text { ñ }\end{array}$ & $\begin{array}{l}8 \\
\stackrel{8}{=} \\
1 \\
1 \\
0 \\
0 \\
0\end{array}$ & 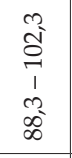 & 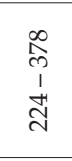 & 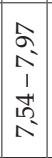 & $\begin{array}{l}R \\
\stackrel{R}{1} \\
10 \\
\stackrel{1}{2}\end{array}$ & $\mid \begin{array}{l}0 \\
0 \\
1 \\
1 \\
0 \\
0\end{array}$ & $\stackrel{\llcorner}{\overrightarrow{\mathrm{V}}}$ & $\begin{array}{l}8 \\
0 \\
0 \\
1 \\
0 \\
0 \\
0\end{array}$ & 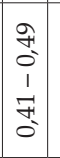 & $\begin{array}{l}0 \\
1 \\
0 \\
1 \\
1 \\
9 \\
0 \\
0\end{array}$ & $\begin{array}{l}8 \\
8 \\
0 \\
1 \\
1 \\
0 \\
0 \\
0\end{array}$ & $\begin{array}{l}2 \\
0 \\
0 \\
1 \\
0 \\
0 \\
0\end{array}$ \\
\hline 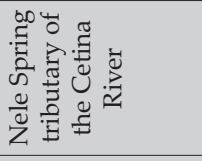 & 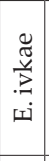 & 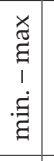 & \begin{tabular}{l}
\multirow{N}{N}{} \\
1 \\
1 \\
2
\end{tabular} & 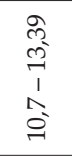 & 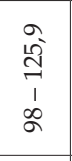 & $\begin{array}{l}\infty \\
0 \\
\infty \\
1 \\
\infty \\
\infty \\
\text { N }\end{array}$ & $\mid \begin{array}{c}2 \\
\infty \\
\infty \\
1 \\
1 \\
\infty \\
\infty \\
N^{\circ}\end{array}$ & $\begin{array}{l}12 \\
1 \\
0 \\
7 \\
1 \\
0 \\
1 \\
1\end{array}$ & $\mid \begin{array}{l}0 \\
0 \\
1 \\
1 \\
0 \\
0\end{array}$ & $\stackrel{\leftrightarrow}{\overrightarrow{\mathrm{V}}}$ & $\begin{array}{l}\text { T } \\
0 \\
1 \\
1 \\
0 \\
0\end{array}$ & $\begin{array}{l}3 \\
3 \\
0 \\
1 \\
1 \\
2 \\
0 \\
0\end{array}$ & $\begin{array}{l}\text { J } \\
0 \\
1 \\
1 \\
0 \\
0\end{array}$ & $\begin{array}{l}8 \\
8 \\
0 \\
1 \\
1 \\
0 \\
8 \\
0 \\
0\end{array}$ & $\begin{array}{l}1 \\
0 \\
0 \\
1 \\
0 \\
0 \\
0\end{array}$ \\
\hline 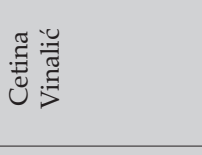 & 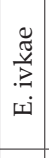 & 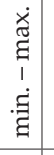 & 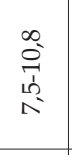 & $\begin{array}{l}m \\
\Rightarrow \\
1 \\
1 \\
0 \\
0 \\
=1\end{array}$ & $\begin{array}{l}0 \\
\infty \\
0 \\
1 \\
\hat{\varnothing} \\
\infty\end{array}$ & $\begin{array}{l}\infty \\
\infty \\
1 \\
1 \\
N \\
\end{array}$ & $\mid \begin{array}{c}0 \\
0 \\
\infty \\
1 \\
0 \\
0 \\
1 \\
1\end{array}$ & $\begin{array}{l}\overline{1} \\
1 \\
1 \\
1 \\
\end{array}$ & $\mid \begin{array}{l}\infty \\
0 \\
1 \\
0 \\
0 \\
0\end{array}$ & $\stackrel{\llcorner}{\overrightarrow{\mathrm{V}}}$ & $\begin{array}{l}-1 \\
0 \\
0 \\
1 \\
0 \\
0 \\
0\end{array}$ & 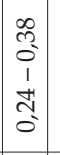 & 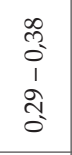 & 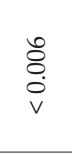 & $\begin{array}{l}0 \\
0 \\
0 \\
1 \\
5 \\
0 \\
0\end{array}$ \\
\hline 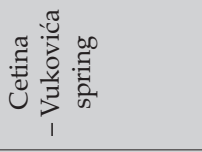 & 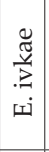 & 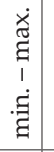 & 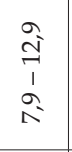 & $\begin{array}{l}\text { ते } \\
0 \\
0 \\
1 \\
8 \\
0 \\
\text { a. }\end{array}$ & $\begin{array}{l}0 \\
5 \\
1 \\
1 \\
+ \\
+\infty\end{array}$ & $\begin{array}{l}\text { N } \\
\text { O } \\
1 \\
\text { D }\end{array}$ & $\mid \begin{array}{c}0 \\
2 \\
\infty \\
1 \\
1 \\
1 \\
1 \\
1 \\
1\end{array}$ & \begin{tabular}{l}
10 \\
\multirow{1}{1}{} \\
1 \\
ปิ
\end{tabular} & $\mid \begin{array}{l}0 \\
0 \\
1 \\
1 \\
0 \\
0\end{array}$ & $\stackrel{\llcorner}{\overrightarrow{\mathrm{V}}}$ & $\begin{array}{l}\tilde{O} \\
\dot{0} \\
v\end{array}$ & $\mid$\begin{tabular}{c|c}
0 \\
1 \\
0 \\
0 \\
1 \\
2 \\
0 \\
0 \\
0
\end{tabular} & \begin{tabular}{l}
0 \\
\multirow{2}{0}{} \\
1 \\
1 \\
3 \\
0
\end{tabular} & $\begin{array}{l}8 \\
8 \\
0 \\
\dot{0} \\
\mathrm{~V}\end{array}$ & $\begin{array}{l}1 \\
0 \\
0 \\
1 \\
5 \\
0 \\
0\end{array}$ \\
\hline 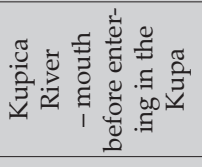 & 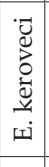 & 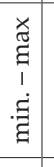 & $\begin{array}{l}3 \\
0 \\
1 \\
1 \\
\infty \\
\infty\end{array}$ & $\begin{array}{l}8 \\
8 \\
1 \\
1 \\
0 \\
\vdots \\
=\end{array}$ & 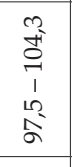 & $\begin{array}{l}\text { +1 } \\
\text { 1 } \\
\text { ลิ }\end{array}$ & $\mid \begin{array}{c}9 \\
9 \\
\infty \\
1 \\
1 \\
2 \\
\infty \\
\infty \\
0\end{array}$ & $\begin{array}{l}8 \\
2 \\
1 \\
\infty \\
1\end{array}$ & 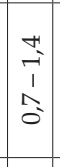 & $\mid \begin{array}{l}0 \\
2 \\
1 \\
1 \\
0 \\
0\end{array}$ & $\begin{array}{l}5 \\
0 \\
0 \\
1 \\
1 \\
8 \\
8 \\
0\end{array}$ & $\mid \begin{array}{c}\infty \\
2 \\
0 \\
1 \\
1 \\
0 \\
0 \\
0 \\
0\end{array}$ & $\begin{array}{l}\text { ב } \\
\frac{1}{1} \\
\frac{10}{0}\end{array}$ & $\begin{array}{l}5 \\
0 \\
0 \\
1 \\
1 \\
\qquad \\
0 \\
0 \\
0\end{array}$ & $\begin{array}{l}0 \\
0 \\
0 \\
1 \\
0 \\
0 \\
0\end{array}$ \\
\hline 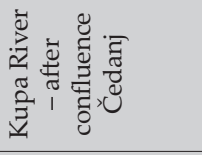 & 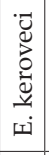 & 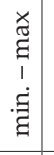 & $\begin{array}{l}0 \\
\infty \\
\stackrel{1}{7} \\
\stackrel{2}{2}\end{array}$ & $\begin{array}{l}0 \\
m^{2} \\
n^{2} \\
1 \\
1 \\
0 \\
0 \\
0\end{array}$ & 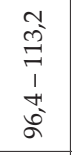 & $\begin{array}{l}\text { d } \\
\text { in } \\
1 \\
0 \\
0 \\
\text { त }\end{array}$ & $\begin{array}{c}0 \\
12 \\
\infty \\
1 \\
1 \\
0 \\
\infty \\
\infty\end{array}$ & 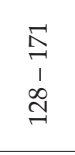 & $\mid \begin{array}{l}0 \\
+ \\
1 \\
1 \\
0 \\
0 \\
0\end{array}$ & $\mid \begin{array}{l}0 \\
0 \\
1 \\
1 \\
0 \\
0\end{array}$ & $\begin{array}{l}8 \\
0 \\
0 \\
1 \\
0 \\
0 \\
0\end{array}$ & $\mid \begin{array}{l}0 \\
-1 \\
1 \\
1 \\
+ \\
0 \\
0\end{array}$ & $\begin{array}{l}\stackrel{+}{-} \\
1 \\
\text { N2 } \\
0\end{array}$ & $\begin{array}{l}5 \\
0 \\
0 \\
1 \\
1 \\
0 \\
0 \\
0 \\
0\end{array}$ & $\begin{array}{l}8 \\
0 \\
0 \\
1 \\
0 \\
0 \\
0\end{array}$ \\
\hline 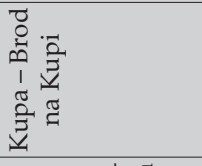 & 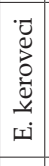 & 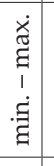 & $\begin{array}{l}\stackrel{0}{1} \\
\stackrel{1}{1} \\
0 \\
\text { i }\end{array}$ & $\begin{array}{l}0 \\
12 \\
0 \\
1 \\
1 \\
0 \\
0 \\
=\end{array}$ & 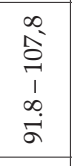 & $\begin{array}{l}\infty \\
\text { N } \\
1 \\
0 \\
\text { ते }\end{array}$ & $\mid \begin{array}{c}0 \\
0 \\
\infty \\
1 \\
1 \\
8 \\
\infty \\
\infty\end{array}$ & $\begin{array}{l}0 \\
\stackrel{0}{1} \\
1 \\
\overrightarrow{7}\end{array}$ & $\begin{array}{c}0 \\
7 \\
1 \\
0 \\
0 \\
0\end{array}$ & $\mid \begin{array}{l}\infty \\
0 \\
0 \\
1 \\
0 \\
0 \\
0\end{array}$ & $\begin{array}{l}0 \\
0 \\
0 \\
1 \\
1 \\
0 \\
0\end{array}$ & $\mid \begin{array}{c}\infty \\
\infty \\
0 \\
0 \\
1 \\
f \\
f \\
0\end{array}$ & $\begin{array}{l}\text { నू } \\
0 \\
1 \\
\tilde{\Omega} \\
0 \\
0\end{array}$ & $\begin{array}{l}8 \\
8 \\
0 \\
1 \\
1 \\
8 \\
0 \\
0\end{array}$ & $\begin{array}{l}8 \\
0 \\
0 \\
1 \\
8 \\
0 \\
0\end{array}$ \\
\hline 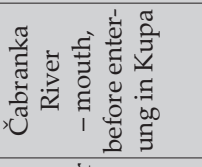 & 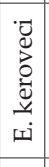 & 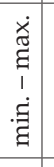 & $\begin{array}{l}\stackrel{+}{2} \\
\stackrel{2}{1} \\
1 \\
0 \\
0\end{array}$ & $\begin{array}{l}9 \\
9 \\
1 \\
1 \\
1 \\
8 \\
0 \\
0 \\
0\end{array}$ & 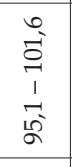 & $\begin{array}{l}\infty \\
\text { N } \\
1 \\
1 \\
\text { त̂ } \\
\text { त̂ }\end{array}$ & $\mid \begin{array}{c}8 \\
0 \\
\infty \\
1 \\
1 \\
0 \\
\infty \\
\infty \\
0\end{array}$ & $\begin{array}{l}0 \\
\text { N } \\
1 \\
1 \\
\stackrel{2}{n}\end{array}$ & $\begin{array}{l}0 \\
0 \\
1 \\
1 \\
0 \\
0\end{array}$ & 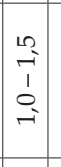 & $\begin{array}{l}0 \\
0 \\
0 \\
1 \\
10 \\
0 \\
0 \\
0\end{array}$ & 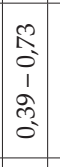 & $\begin{array}{l}1 \\
\infty \\
0 \\
1 \\
1 \\
\infty \\
+ \\
0\end{array}$ & $\begin{array}{l}5 \\
0 \\
0 \\
1 \\
1 \\
0 \\
8 \\
0 \\
0\end{array}$ & $\begin{array}{l}0 \\
0 \\
0 \\
1 \\
0 \\
0 \\
0\end{array}$ \\
\hline 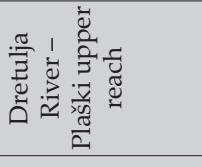 & 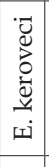 & 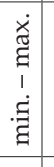 & \begin{tabular}{l} 
웅 \\
\multirow{2}{1}{} \\
0 \\
0
\end{tabular} & 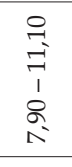 & $\begin{array}{l}\hat{1} \\
2 \\
1 \\
1 \\
\\
0\end{array}$ & $\begin{array}{l}\frac{20}{9} \\
\frac{1}{1} \\
\stackrel{2}{m}\end{array}$ & $\mid \begin{array}{c}0 \\
0 \\
\infty^{-} \\
1 \\
0 \\
0 \\
n^{2}\end{array}$ & $\begin{array}{l}\text { ลิ } \\
1 \\
2 \\
\end{array}$ & $\begin{array}{c}10 \\
7 \\
1 \\
0 \\
0\end{array}$ & $\mid$\begin{tabular}{c}
+1 \\
\multirow{2}{*}{} \\
1 \\
1 \\
0 \\
0
\end{tabular} & $\begin{array}{l}7 \\
= \\
0 \\
1 \\
8 \\
0 \\
0\end{array}$ & $\begin{array}{l}3 \\
-1 \\
1 \\
2 \\
0 \\
0\end{array}$ & $\begin{array}{l}\text { Ln } \\
\stackrel{1}{1} \\
\text { No } \\
0\end{array}$ & $\begin{array}{l}1 \\
0 \\
0 \\
1 \\
1 \\
0 \\
0 \\
0\end{array}$ & $\begin{array}{l}3 \\
0 \\
0 \\
1 \\
5 \\
0 \\
0\end{array}$ \\
\hline 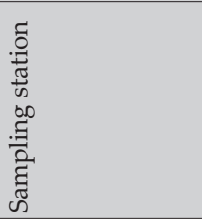 & 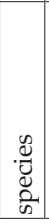 & & 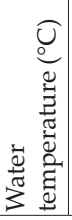 & 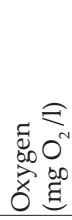 & 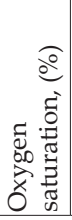 & 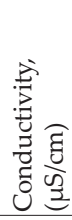 & $\frac{T}{2}$ & 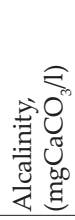 & 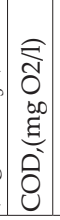 & 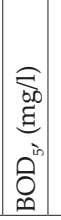 & 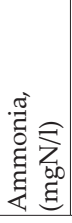 & 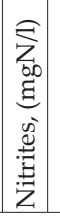 & 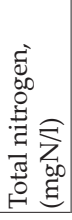 & 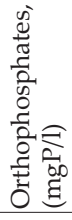 & 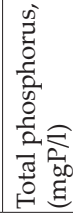 \\
\hline
\end{tabular}


govina Herzegovina (Marinković-Gospodnetić, 1979; Kučinić et al., 2010; ViteceK et al., 2015). In Croatia Drusus bosnicus Group was present only with species Drusus vespertionis from spring of the River Una (KučınIć et al., 2014) situated in the eastern part of Lička Plješevica Mt. In the western part of Lička Plješevica Mt. and Kamešnica Mt. Drusus bosnicus Group is not distributed.

\section{Ecology}

The habitat characteristics of the localities where E. keroveci was recorded indicate that the species prefers rhithral sections of streams with substrates mainly composed of mesolithal and macrolithal that is substantially covered with algae and moss. Like investigation of Previšić et al., 2014 we also found similar habitat characteristics.

The habitat characteristics of the localities where E. ivkae was recorded indicate that the species has a preference mostly for crenal sections of stream, but may also colonize rhithral sections (Previšić et al., 2014), which is supported by our findings of the species in the Rumin River. The substrate in rivers inhabited by E. ivkae was mainly composed of smaller fractions (microlithal and mesolithal) with some larger stones and submerged vegetation at all three locations in the Cetina River and the two locations in the Rumin River.

Analysis of physico-chemical parameters (Tab. 2) indicate high or good water quality. Therefore, both species are probably sensitive to organic pollution. E. ivkae is restricted to the spring area, where concentration of organic matter and nutrients are lower than in the middle and lower part of the stream. E. keroveci occurs at locations with a wider range of water temperature, as well as a slight increase in organic matter and concentration of nutrients. Population density of population of larval E. keroveci was much higher at the river mouths than in the upper parts of streams.

Our study and literature data (Previšić et al., 2014) of collected adults indicate that both species, E. kereoveci and E. ivkae have emergence in the spring and summer months (Tab. 1) and suggest that both species have only one generation and a typical one-year life cycle like some other Drusine species from Dinaric karst area (e.g. Kučınić et al., 2010).

\section{Conservation issues}

In the Balkan Peninsula, including some areas in Croatia, considerable numbers of hydropower plants have been planned, many of them focused on mountain springs and spring areas due to their natural hydrological potential. The construction of such hydroelectric facilities can cause changes in morphological and hydrological characteristics at the construction site; consequently, the changed environmental conditions may lead to the endangering or even the loss of certain species. The protection of these habitats is possible, among other things, through protection of endemic and rare species in this area. Due to their limited distribution ranges, both Ecclisopteryx species are likely to be endangered if any water abstraction or water pollution occures.

E. keroveci is not a highly vulnerable species although it requires a certain level of protection. On the other hand, E. ivkae, as microendemic species occurring only at a few localities within the Cetina River catchment area, requires absolute protection. Its protection mostly depends on good water quality as well as sustainable, moderate and reasonable water abstraction in order to supply the local area. Successful examples of such 
spring protection and water use management of springs that also serve as water supply have been implemented at Brljan spring near Smiljan in Lika (Croatia), where one of the most isolated population of Drusus croaticus occurs (Kučinić et al., 2008; Previšić et al., 2009). Another good example is the spring of Paljinska Miljacka (Bosnia and Herzegovina), inhabited by the endemic Drusus bosnicus (KučInIć et al., 2015). It is important to establish the eco-agriculture without the use of pesticides and herbicides, because the species E. ivkae was recorded in the agricultural field.

We consider that all springs and spring areas should be protected in order to preserve habitats, species and valuable water resources. If some water abstraction in these areas is required, it should be carried out in a sustainable way so that the fauna occurring there is not affected.

For the species E. ivkae we propose the IUCN category 'critically endangered' and for the species E. keroveci the category 'vulnerable' is suggested (DupLIć et al., 2015; ŠAšić et al., 2015).

\section{ACKNOWLEDGEMENT}

Results presented in this paper are the part of the projects „EU Natura 2000 Integration Project (NIP)" funded by the Croatian Ministry of Environmental and Nature Protection. This research was also financed by the University of Zagreb.

Received October 14, 2016

\section{REFERENCES:}

Bertić, I., LAmpek PAvČNik, I. \& Radovinović, R. 2001: Satelitski atlas Hrvatske. Naklada Ljevak i Gisdata, Zagreb pp. 360.

Duplić, A., Gambiroža, P., Kutleša, P., Opačić, B. \& Ribarić, A., 2015: Natura of Croatia, Capital for the future. State Institut for Nature Protection (Državni zavod za zaštitu prirode Hrvatske), Zagreb, pp. 50.

Graf, W., Murphy, J., Dahl, J., Zamora -Muñoz, C. \& López -RodríGuez, M.J., 2008: Volume 1 - Trichoptera. in: Schmidt-Kloiber, A., Hering, D. (eds), Distribution and Ecological Preferences of European Freshwater Organisms. Pensoft Publishers, Sofia, Moscow. 388 pp.

Graf, W., Kučinić, M., Previšić, A., Paulus, S.U. \& Waringer, J., 2011: The larva Ecclisopteryx malicky Moretti, 1991 (Trichoptera: Limnaephilidae; Drusinae) with comments on the genus. Zoosymposia 5, 136-142.

Graf, W. \& SCHMidT-KLOIBER, A., 2011: Additions to and update of Trichoptera Indicator Database. - www. freswaterecology.info, version 6.0 (accessed on 30 September 2016).

Ibrahimi, H., Kučinić, M., Gashi, G. \& Grapci-Kotor, L., 2014: Trichoptera Biodiversity of the Aegean and Adriatic Sea Basins in the Republic of Kosovo. Journal of Insect Science. 14 (209), DOI: 10.1093/ jisesa/ieu071.

Ibrahimi, H, Kučinić M, Vitecek S, Graf W, Previšić A, Bálint M, Keresztes L, \& Pauls SU., 2015: New records for the Kosovo caddisfly fauna with description of a new species, Drusus dardanicus sp. nov. (Trichoptera: Limnephilidae). Zootaxa 4032, 551-568. doi: 10.11646/ zootaxa.4032.5.5

ILliEs, J., 1978: Limnofauna Europaea. A Checklist of the Animals Inhabiting European Inland Waters, with an Account of their Distribution and Ecology, 2nd Edition. Gustav Fischer Verlag, Stuttgart, 552 pp.

Kučinić, M., Previšić, A., Gottstein, A., Hrašovec, B., Stanić-Koštroman S., Pernek, M. \& Delić, A., 2008: Description of the larvae of Drusus radovanovici septentrionis MARINKović-Gospodnetić, 1976 and Drusus croaticus Marinković-Gospodnetić, 1971 (Trichoptera: Limnephilidae) from Bosnia and Herzegovina and Croatia. Zootaxa, 1783, 1-17. 
Kučinić, M., Previšić, A., Stanić-Koštroman S., Franjević, M., Šerić Jelaska L., Delić, A. \& Posilović, H., 2010: Description of the larvae of Drusus ramae Marinković-Gospodnetić and Drusus medianus Marinković-Gospodnetić (Trichoptera: Limnephilidae) with some genetic, distributional, ecological, faunal and conservation notes. Zootaxa 2484, 1-24

Kučinić, M., Delić, A., Ćuk, R., Previšić, A., Mihoci, I., Žganec, K., Cerjanec, D. \& VučKović, I., 2014 : The first finding of Drusus bosnicus Group (Insecta, Trichoptera, Limnephilidae) in Croatia with some notes on diversity, distribution and ecology of genus Drusus in Croatia and in Dinaric karst of the Balkan Peninsula. Natura Croatia, 23 (2), 265-377.

Kučinić M, Previšić A, Graf W, Mihoci I, Šoufek M, Stanić-Koštroman S, Lelo S, Vitecek S, \& WarinGER J., 2015: Larval description of Drusus bosnicus Klapálek 1898 (Trichoptera: Limnephilidae) with distributional, molecular and ecological features. Zootaxa 3957, 85-97. doi: 10.11646/zootaxa.3957.1.7

Kučinić, M., Previšıć, A., Mihoci, I., Krpač, V., Žıvič, I., Stojanović, K., Mrnjavčić Vojvoda, A. \& Katušıć, L. 2016: Morphological features of larvae of Drusus plicatus Radovanović (Insecta, Trichoptera) from the Republic of Macedonia with molecular, ecological, ethological and distributional notes. Zookeys 598, 75-97

Malicky, H., 2004: Atlas of European Trichoptera, Second Edition, Springer, 359 pp.

Marinković-Gospodnetić, M., 1970: Fauna Trichoptera područja Maglića, Volunjaka i Zelengore. Glasnik zemaljskog muzeja Bosne i Hercegovine (nova serija) 9, 107-119.

Marinković-Gospodentić, M., 1978: The caddis-flies (Trichoptera, Insecta) of Hercegovina (Yugoslavia). Godišnjak Biološkog Instituta Univerziteta Sarajevo (Annual of the Institute of Biology - University of Sarajevo) 31, 115-131.

Marinković-Gospodnetić, M., 1979: Trichoptera (Insecta) velikih karstnih izvora u Dinaridima. In: Rauš, Đ. (Ed.). Drugi kongres Ekologa Jugoslavije (Second Congress of Ecologists of Yugoslavia). Savez društava ekologa Jugoslavije, Zagreb. 1837-1849.

Narodne Novine, 2008: Strategija upravljanja vodama (Water Management Strategy). No. 91/08.

Narodne Novine, 2013: Uredba o standardu kakvoće voda (Regulation on water quality standard). No.73/13.

NARodne Novine, 2014: Uredba o izmjenama i dopunama uredbe o standardu kakvoće voda (Regulation on amendments to the Regulation on water quality standard). No. 151/14.

OlÁH, J. \& Kovács, T., 2014: New species and records of Balkan Trichoptera III. Folia Historico Naturalia Musei Matraensis 38, 97-131.

Previšić, A., Walton, C., Kučinić, M., Mitrikeski, P. T. \& Kerovec, M., 2009: Pleistocene divergence of Dinaric Drusus endemics (Trichoptera, Limnephilidae) in multiple refugia within the Balkan Peninsula. Molecular Ecology, 18 (4), 634-647.

Previšić, A. \& PopijAč, A., 2010: Caddisfly (Insecta: Trichoptera) fauna of Kupa and Čabranka rivers and their tributaries, Gorski kotar, W Croatia. Natura Croatica 19 (2), 357-368.

Previšić, A., Ivković, M., Miliša, M. \& Kerovec, M., 2013: Caddisfly (Insecta: Trichoptera) fauna of the Papuk Nature Park, Croatia. Natura Croatica 22 (1), 1-13.

Previšić, A., Graf, W., Vitecek, S., Kučinić, M., Bálint, M., Keresztes, L., Pauls, S.U. \& Waringer, J., 2014: Cryptic diversity of caddisflies in the Balkans: the curious case of Ecclisopteryx species (Trichoptera: Limnephilidae). Arthropod Systematics \& Phylogeny 72 (3), 309-329.

Radovanović, M., 1935: Trichoptere Jugoslavije. Glasnik zemaljskog muzeja u Sarajevu 47, 73-84. SịpahịLER, F., 2015: Two new species of the genus Ecclisopteryx Kolenati from Turkey (Trichptera, Limnephilidae, Drusinae). Nova Acta Cientifica Compostelana (Bioloxia), 22, 69-74.

Stanić-Koštroman., S., Kučinić, M., Kolobara, A., ŠKobić, D., Knezović, L. \& Durbešić, P., 2012: Lighttrapped caddisflies (Insecta:Trichoptera) as indicators of the ecological integrity of the Lišica River, Bosnia and Herzegovina. Entomologica Croatica 16, Num1-4; 21-36.

Stanić-Koštroman., S., Previšić, A., Planinić A., Kučinić, M., ŠKobić, D., Dedić, A. \& Durbešić, P., 2015 : Enviromental determinants of contrasting caddisfly Bosna river basins (Bosnia and Herzegovina) under temperate and mediterranean climates. International Review of Hydrobiology, 100: $79-95$

ŠAšıć, M., MiHoci, I. \& Kučınıć, M. 2015: Crvena knjiga danjih leptira Hrvatske. Državni zavod za zaštitu prirode Hrvatske i Hrvatski prirodoslovni muzej, Zagreb, pp. 164.

Vitecek, S., Kučinić, M., Oláh, J., Previšić, A., Bálint, M., Keresztes, L., Waringer, J., Pauls, S.U. \& Graf, W., 2015: Description of two new filtering carnivore Drusus species (Limnephilidae, Drusinae) from the Western Balkans. Zookeys 513, 79-104. 
Vučković, I., Previšić, A., Graf, W. \& Kučinić, M., 2011: Description of the female and distribution of Annitella apfelbecki Klapálek, 1899 (Insecta: Trichoptera). Aquatic Insects, 33 (4), 381-389.

Vučković, I., 2011: Faunističke, taksonomske i ekološke značajke tulara (Insecta:Trichoptera) sliva rijeke Cetine. Sveučilište u Zagrebu, Prirodoslovno-matematički fakultet, Doktorska disertacija, 176 pp.

WARINGER, J. \& GRAF, W., 2011: Atlas der mitteleuropäischen Köcherfliegenlarven/Atlas of Central European Trichoptera Larvae. Über 600 Farbfotos.- 468 pp. (Erik Mauch Verlag) Dinkelscherben.

\section{SAŽETAK}

\section{Rod Ecclisopteryx (Insecta: Trichoptera: Limnephilidae) u Hrvatskoj: rasprostranjenost $i$ aspekti zaštite}

I. Vučković, R. Ćuk, D. Cerjanec, I. Vidaković, M. Plantak, M. Srebočan \& M. Kučinić

U posljednja tri desetljeća provode se detaljnija istraživanja faune tulara u Hrvatskoj (Cetina, Drava, Dobra, Krka, Kupa, Kupica i druge rijeke) prema kojima je, uz postojeće literaturne podatke, do sada zabilježeno oko 200 vrsta tulara. U radu su prikazani novi nalazi za vrstu Ecclisopteryx ivkae na slivnom području rijeke Cetine i nalazi vrste Ecclisopteryx keroveci na slivnom području Kupe i rijeci Veličanki tijekom istraživanja koja su provedena u razdoblju 2014.-2015. godine (NIP projekt) te na osnovu nacionalnog monitoringa kakvoće površinskih voda u sklopu kojeg su prikupljene ličinke ovih vrsta. U radu su predložene i mjere zaštite za obje vrste te status njihove ugroženosti prema IUCN kriterijima. 